\title{
Microphytobenthos from two subtidal sediments from North Brittany. II. Variations of pigment compositions and concentrations determined by HPLC and conventional techniques
}

\author{
Catherine Riaux-Gobin ${ }^{1}$, Carole A. Llewellyn ${ }^{2}$, Bert Klein ${ }^{1}$ \\ ${ }^{1}$ CEOBM, Station Biologique, Place Georges Teissier, F-29211 Roscoff, France \\ ${ }^{2}$ IMER, Prospect Place, The Hoe, Plymouth PL1 3DH, United Kingdom
}

\begin{abstract}
Pigment composition and concentration of 2 temperate subtidal sediments, a mud and a sand from North Brittany, were studied using HPLC and conventional fluorometric methods. Pigment diversity, found using HPLC, was considerable, particularly in the mud (around 15 identified pigments). Pigment composition in the sand was dominated by Bacillariophyceae pigments, whereas in the mud pigments characteristic of Chlorophyceae were also found. Freeze-drying significantly reduces pigment concentrations.
\end{abstract}

\section{INTRODUCTION}

The quantitative importance of marine benthic microphytes and their role in coastal food webs has long been underestimated. The microphytobenthos colonizes all intertidal and subtidal substrates (Round 1971). Several authors (e.g. Cadée \& Hegeman 1974, Sournia 1977, Joint 1978, Asmus 1982) have compared pelagic and benthic primary production, and all point out the importance of benthic primary producers. The measurement of chlorophyll a has been widely used to estimate microphytic biomass.

In sediments, pigments originate from numerous sources: in situ microphytobenthos (living and detrital), sedimentation of degraded phytoplankton, and other allochthonous detrital material (from macrophytes, marsh, faecal pellets, continental and riverine particles, etc.).

Conventional methods used to estimate chloropigment concentrations in sediments have been adapted from methods used in plankton research: the fluorometric method (Yentsch \& Menzel 1963, HolmHansen et al. 1965, Lorenzen 1966) and the spectrophotometric methods (trichromatic: Strickland \& Parsons 1968; acidification method: Lorenzen 1967). These methods do not take into account the great diversity of the pigments present in sediments. Furthermore, in these conventional methods, the so-called 'chlorophyll $a$ ' groups chlorophyll $a$, its allomers and isomers and chlorophyllide $a$. Also the presence of chls $b$ and $c$ interferes with the chl a determination (Lorenzen \& Jeffrey 1980). The term 'phaeopigments', often called 'phaeophytin $a$ ' in the past, also includes many degradation products (several phaeophytins and phaeophorbides). Phaeopigments are quantitatively important in sediments (Plante-Cuny 1974, Riaux 1982). Recently it was shown that phaeopigment concentrations can be overestimated by $30 \%$ using the fluorometric technique (Conover et al. 1986).

Chromatographic techniques (Thin Layer Chromatography, TLC, and High Performance Liquid Chromatography, HPLC) have been used extensively for the estimation of pigment concentrations in plankton (e.g. Abaychi \& Riley 1979, Jeffrey 1981, Mantoura \& Llewellyn 1983) whereas these methods have up to now scarcely been used in sediments (Brown et al. 1981, Daemen 1986). With these methods nearly all pigments and their degradation products can be separated and accurately quantified. Not only the individual chlorophyll concentration can be determined but also those of other light-harvesting pigments such as the carotenoids fucoxanthin and peridinin (Jeffrey 
1980). The pigment composition can also be used for taxonomic purposes, since several pigments or pigment combinations are found only in certain algal classes (van den Hoek 1978). Comparisons of conventional and HPLC techniques have been carried out by several authors (Brown et al. 1981, Jacobsen 1982, Mantoura \& Llewellyn 1983, Gieskes \& Kraay 1984, Hafsaoui 1984, Sartory 1985, Trees et al. 1985, Daemen 1986), but results are somewhat contradictory.

The aim of the present study is to assess the type and relative abundances of chlorophylls, their degradation products, and carotenoids in 2 contrasting subtidal sediments from the North Brittany coast of France during different seasons and also to compare this with the input from overlying waters. The HPLC method has been used in order to determine precisely the pigment compositions - particularly degration products - and its seasonal variations, keeping in mind that it can be a 'finger-print' of the composition and evolution of the microphytic community. The results have been compared with those obtained with the fluorometric method. The effect of freeze-drying frozen samples is also discussed.

This study is Part II of a more extensive description. Part I (Riaux-Gobin unpubl.), describes in detail the seasonal variations of 'chlorophyll a' and 'phaeopigments' (conventional methods), and its depth distribution in the 2 sediments. Part III (Riaux-Gobin et al., 1987) analyses relations between microphytic biomass and pore-water nutrient concentrations.

\section{MATERIALS AND METHODS}

Sediment cores were taken from 2 North Brittany locations (Fig. 1) during different seasons:

(1) A subtidal well-sorted sand from Pierre Noire, at $20 \mathrm{~m}$ depth in Morlaix Bay, was sampled on $28 \mathrm{Feb}, 13$ May and 10 Jun 1985. Hydrological and climatic parameters at this station have been described by Boucher et al. (1984) and Dauvin (1984).

(2) A subtidal mud from Frêt, at $10 \mathrm{~m}$ depth in Rade de Brest, was sampled on 1 Mar and 14 Jun 1985. Tréguer et al. (1985) have described chemical parameters at this site.

The cores were obtained with an automatic Rouvillois corer with plexiglass tubes $(4.5 \mathrm{~cm}$ diameter). Cores were deep-frozen $\left(-20^{\circ} \mathrm{C}\right) 1$ to $3 \mathrm{~h}$ after sampling. After thawing, the cores were cut into several layers. Only results concerning the top $5 \mathrm{~mm}$ layer and a deeper layer $(6$ to $8 \mathrm{~cm}$ ) will be discussed here. Each layer was manually homogenized and subsampled for the different analyses. Subsamples were taken for moisture determination by drying at $60^{\circ} \mathrm{C}$ for $48 \mathrm{~h}$. Subsamples for fluorometric analysis were immediately

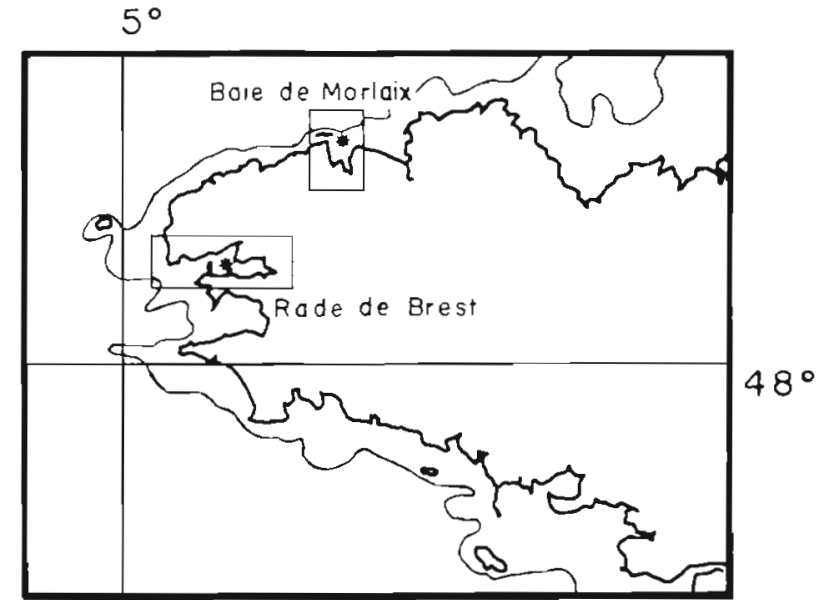

Fig. 1. Sampling locations (stars) in the Rade de Brest (Frêt) and the Baie de Morlaix (Pierre Noire), North Brittany

extracted and those for HPLC analysis were immediately extracted or/and freeze-dried for delayed analysis

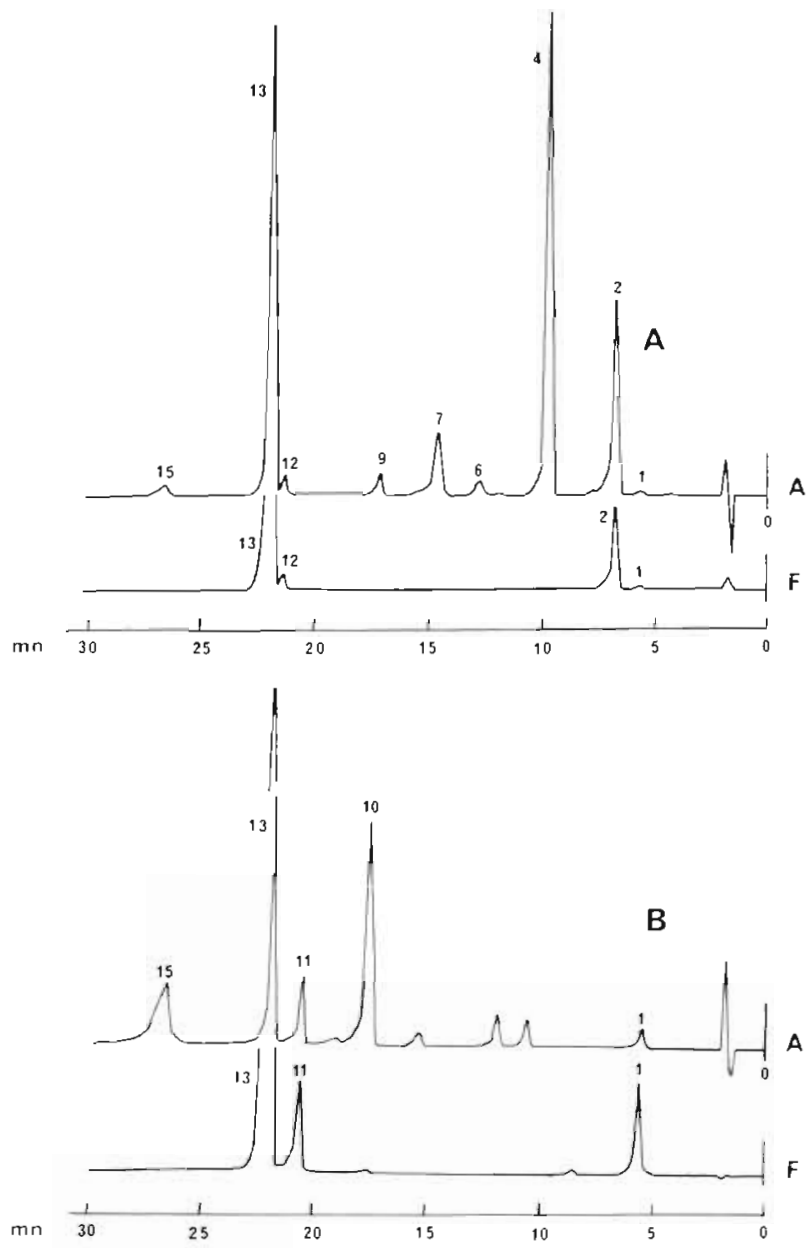

Fig. 2. Chromatograms of cultures of (A) the diatom Nitzschia closterium (isolated from sediment), and (B) the green alga Dunaliella tertiolecta. A: absorbance; F: fluorescence. For meaning of numbers see Table 1. 
Samples for fluorometric analysis $1 \mathrm{~g} \pm 0.0001 \mathrm{~g}$ wet weight) were extracted in $10 \mathrm{ml} 90 \%$ acetone (MERCK) and kept cool $\left(4^{\circ} \mathrm{C}\right)$ and dark for $24 \mathrm{~h}$. $\mathrm{MgCO}_{3}$ was not used. Samples were manually shaken twice during extraction. Immediately before analysis the samples were centrifuged for $2 \mathrm{~min}$ at $2000 \mathrm{rpm}$. The fluorescence of a $6 \mathrm{ml}$ aliquot was measured on a Turner 111, equiped with a phototube R 136, before and after acidification with $80 \mu 11 \mathrm{~N} \mathrm{HCl}$. Chlorophyl $a$ and phaeopigment concentrations were calculated according to the equations of Holm-Hansen et al. (1965) and Lorenzen (1966). All manipulations were performed under dim light conditions. Reproducibility of the method is around $5 \%$ (subsamples) whereas the standard deviation of duplicate samples depends upon the sediment nature.

The HPLC analyses were carried out as described by Mantoura \& Llewellyn (1983) with slight modifications and Klein \& Sournia (1987). Reproducibility of weighing, extraction and HPLC injection was about $5 \%$ and that of replicate injection was about $1 \%$. Chlorophylls were quantified using chlorophyll $a$ and $b$ standards (Sigma Chemical Company Ltd). Chlorophyll a was converted to chlorophyllide a using chlorophyllase enzyme and by acidification into phaeophorbide $a$. Phaeophytin a was produced by acidification of standard chlorophyll a. Identification of carotenoids was by retention time comparison with standard cultures and by on-line spectra collection using a photo-diode array liquid chromatography spectrophotometric detector (Hewlett Packard 1040 a). Chromatograms of diatom (Nitzschia closterium, isolated from sediment) and green alga (Dunaliella tertiolecta) cultures are shown in Fig. 2 (the numbers are explained in Table 1).

All results are given in $\mu \mathrm{g} \mathrm{g}^{-1}$ dry weight of sediment (DW).

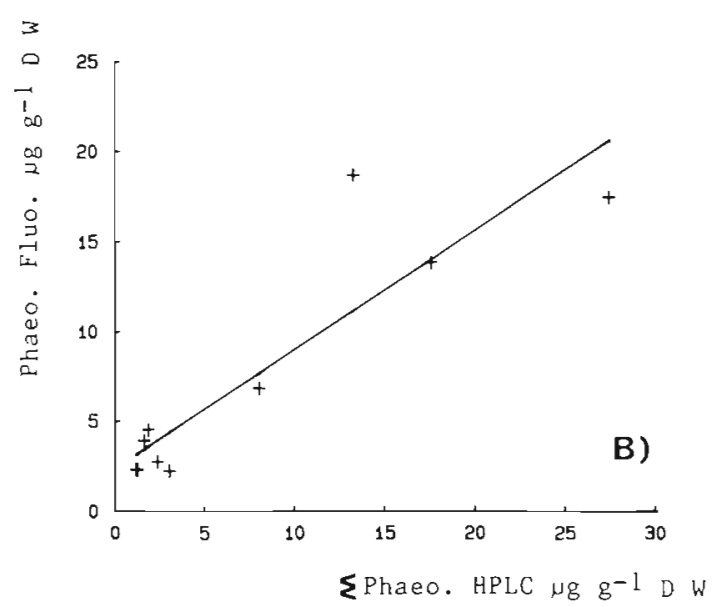

Table 1. Pigments identified in the sediments from Pierre Noire (Morlaix Bay) and Frêt (Rade de Brest). The numbers are used in Fig. 2, 3, 5 \& 6

\begin{tabular}{|c|c|c|c|}
\hline Chlorophyllide a & 1 & Diatoxanthin & 9 \\
\hline Chlorophyll c & 2 & Lutein & 10 \\
\hline Phaeophorbide a & 3 & Chlorophyll $b$ & 11 \\
\hline Fucoxanthin & 4 & Chlorophyll & \\
\hline Phaeophorbide & & a-allomer & 12 \\
\hline a-like & 5 & Chlorophyll a & 13 \\
\hline Neofucoxanthin & 6 & $\alpha$-carotene & 14 \\
\hline Diadinoxanthin & 7 & $\beta$-carotene & 15 \\
\hline Alloxanthin & 8 & Phaeophytin a & 16 \\
\hline
\end{tabular}

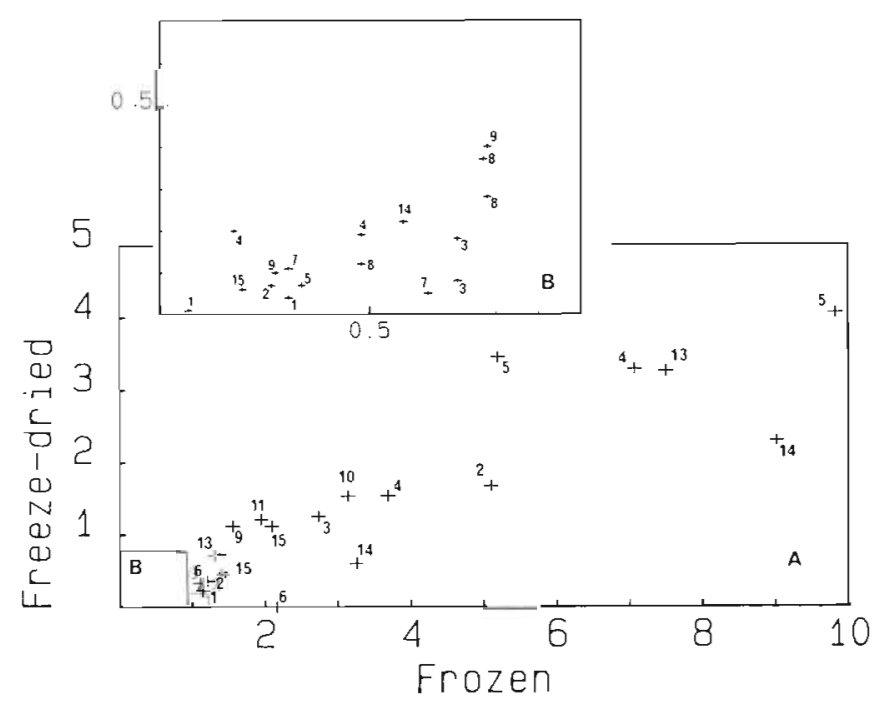

Fig. 3. Correlation between 2 sets of HPLC data from the 2 sampling locations. Abscissa: frozen subsamples; ordinate: frozen then freeze-dried subsamples $\left(\mu \mathrm{g} \mathrm{g}^{-1} \mathrm{DW}\right)$. (A) High values; (B) low values. For meaning of numbers, see Table 1

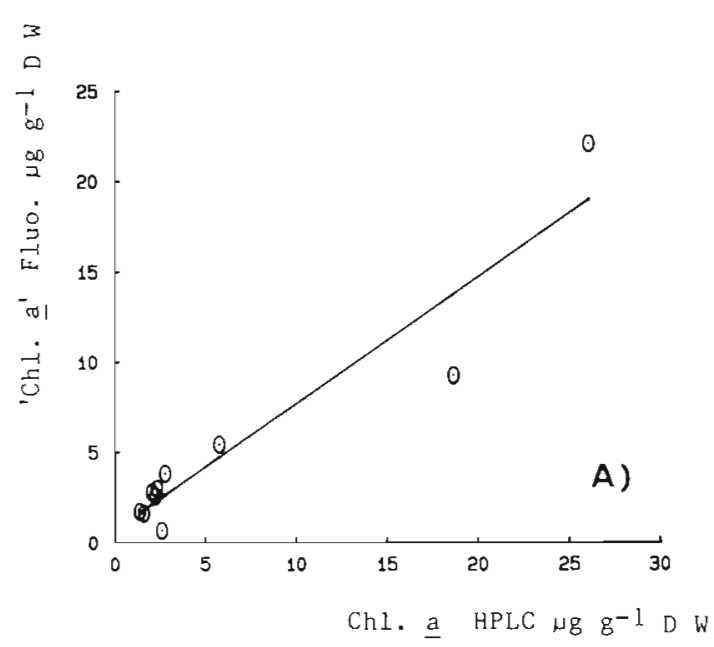

Fig. 4. Linear regression between results obtained by the HPLC (freeze-dried samples) and conventional fluorometric methods (frozen samples). (A) Chlorophyll $a(y=0.70 x+0.69 ; r=0.95 n=10) ;(B)$ phaeopigments $(y=0.66 x+2.38 ; r=0.90 n=10)$ 


\section{RESULTS}

\section{Influence of freeze-drying}

Some samples were analysed twice by HPLC: one subsample was deep-frozen prior to analysis and the other was also freeze-dried. Freeze-drying reduces the pigment concentrations in sediments by up to $90 \%$ (mean about $60 \%$ ) (Fig. 3 ; for the meaning of the numbers see Table 1); some pigments are more affected by freeze-drying than others. The increase in retention time on the HPLC chromatograms for the phaeophorbide a-like pigments suggests that these pigments become less polar after freeze-drying.

\section{Comparison of the two methods}

Chlorophyll a concentrations in sediments, obtained with the fluorometric method and HPLC, show a good correlation (Fig. 4A); the regression line is always lower than the $x=y$ line, whatever the pretreatment of the HPLC samples (Fig. 4A; freeze-dried HPLC samples, $\mathrm{y}=0.70 \mathrm{x}+0.69 ; \mathrm{r}=0.95, \mathrm{n}=10)$. Underestimations by the fluorometric method (or overestimation by the HPLC technique) was also reported by Trees et al. (1985) and Gieskes \& Kraay (1986), whereas several
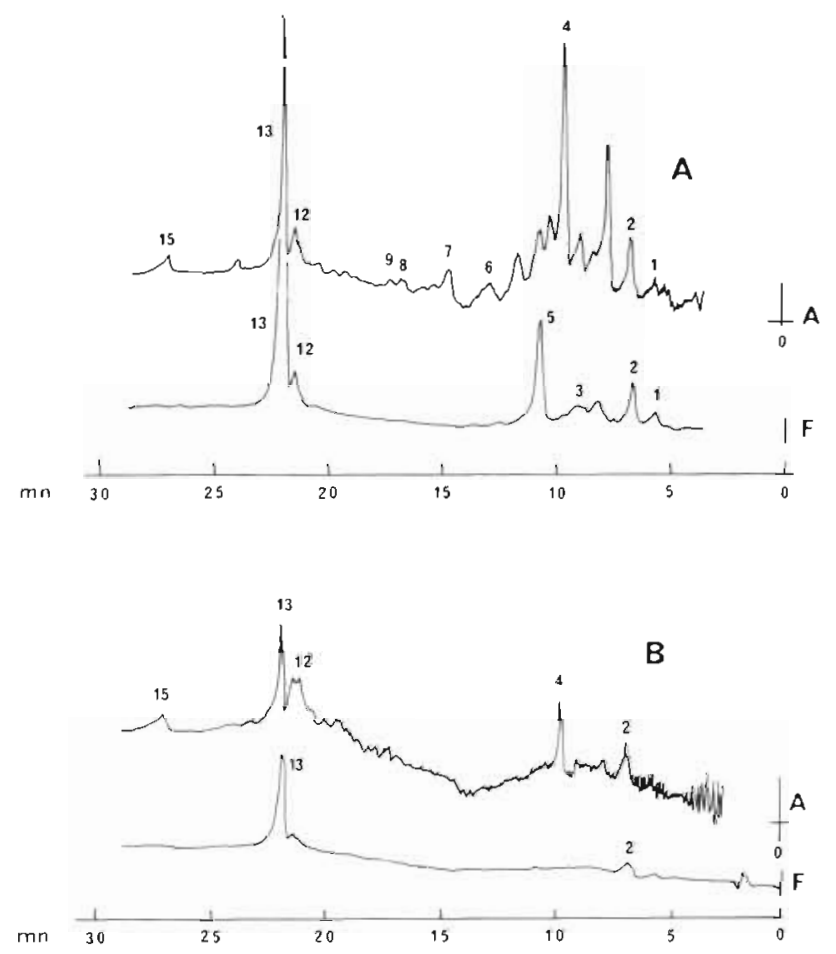

Fig. 5. HPLC chromatograms of a sediment sample from Pierre Noire (summer 1985) (A) Surface layer $(0$ to $0.5 \mathrm{~cm}$ ); (B) 6 to $8 \mathrm{~cm}$ layer $A$ : absorbance; $F$ : fluorescence. For meaning of numbers, see Table 1 authors such as Gieskes \& Kraay (1986) and Daemen (1986) noticed overestimating by the fluorometric method. Phaeopigment concentrations obtained with this technique also show a very good correlation with the sum of the concentrations of the different phaeopigments (mainly phaeophorbides) as obtained by HPLC (Fig. $4 \mathrm{~B}_{i} \mathrm{r}=0.90, \mathrm{n}=10$ ).

The slopes of the 2 regression lines (Fig. $4 \mathrm{~A}, \mathrm{~B}$ ) are not statistically different (Student test: $\mathrm{t}=3.72 \times 10^{-1}$, $v=18$ ) but the phaeopigment regression line is systematically above that of chlorophyll $a_{\text {; }}$ this shift would be more evident if we had considered, in the abscissa, the sum of all the chloropigments interfering in the 'chlorophyll a' values obtained by the conventional method, instead of HPLC chlorophyll $a$ only. The shift may partly originate from the differences between the molecular weights of phaeophytins a and phaeophorbides $a$, for which the equations used in the fluorometric method are not corrected (Conover et al. 1986).
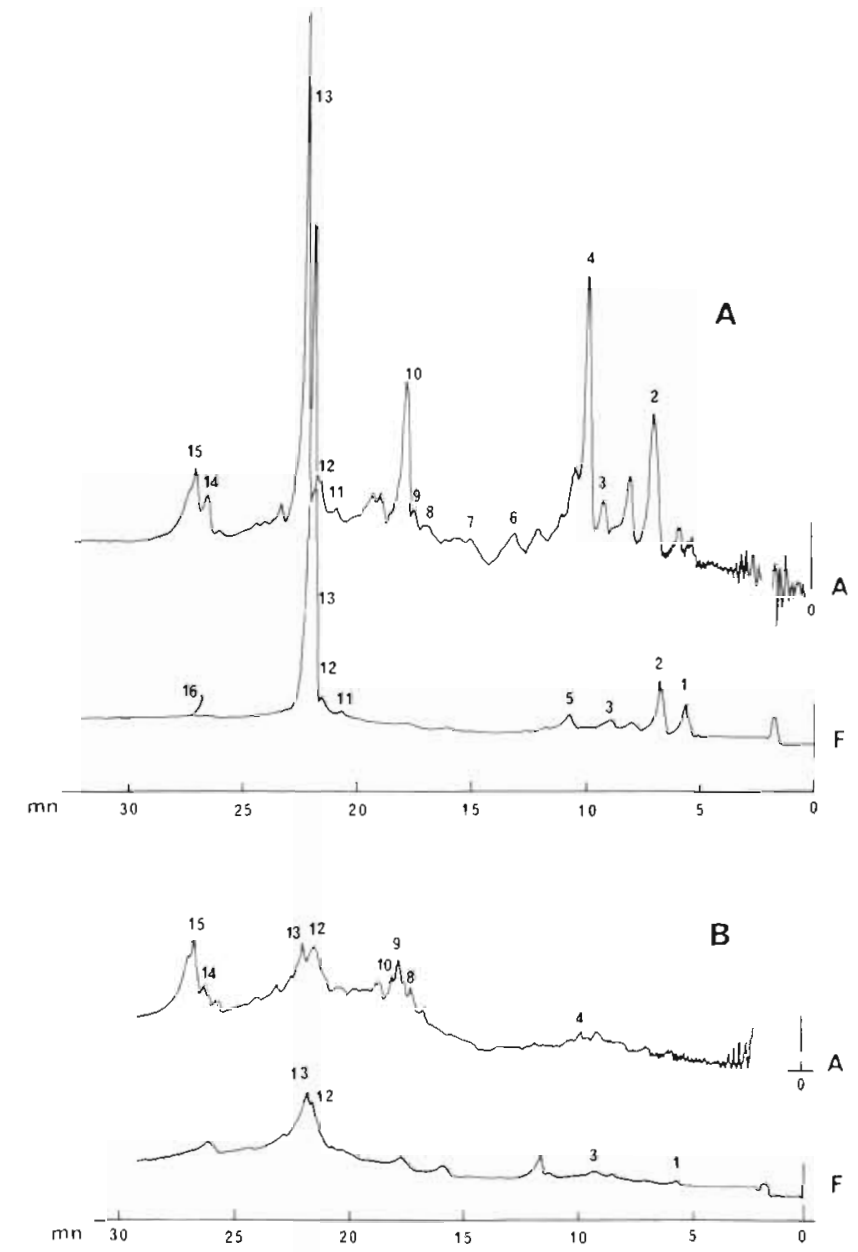

Fig. 6. HPLC chromatograms of a sediment sample from Frêt (summer 1985). (A) Surface layer (0 to $0.5 \mathrm{~cm}$ ); (B) 6 to $8 \mathrm{~cm}$ layer. A: absorbance; F: fluorescence For meaning of numbers, see Table 1 
Pigment composition, spatial and temporal variations

The quantitatively most important pigments in the subtidal sand from Pierre Noire are chlorophyll a, fucoxanthin, chlorophyll $b$ and phaeophorbide a-like pigments (Fig. 5). Chlorophyll $c$ and fucoxanthin indicate the presence of a dominating Bacillariophyceae population and chlorophyll $b$ indicates the presence of Chlorophyceae and/or Euglenophyceae (van den Hoek 1978).

In the subtidal mud from the Rade de Brest, the pigment composition is more diverse (Fig. 6). The presence of Bacillariophyceae is indicated by chlorophyll $c$ and fucoxanthin; alloxanthin and $\alpha$-carotene are specific to Cryptophyceae, whereas the high concentrations of chlorophyll $b$ and lutein indicate important populations of Chlorophyceae. The absence of myxoxanthophyll and zeaxanthin indicates that Cyanobacteria are not important in the microphytobenthic community of the 2 sites.

Pigment concentrations were generally much higher in the mud than in the sand (Tables $2,3 \& 4 ;$ e.g. mean chl $a$ concentrations are 15 and $4 \mu \mathrm{g} \mathrm{g}^{-1}$ DW respectively). This is not surprising, since the sediment at Pierre Noire is a well sorted sand and strong currents prevent microphytes growing well at the sediment surface. In contrast the mud of Frêt (Rade de Brest) is a more stable sediment and can be highly colonized by microphytes at periods with good light penetration. The values correspond well with those obtained during the years $1978-80$ at Pierre Noire (seasonal range of variation 1 to $10 \mu \mathrm{g} \mathrm{chl} \mathrm{g} \mathrm{g}^{-1} \mathrm{DW}$ ) and an intertidal mud from the Morlaix Bay (range 3 to $40 \mu \mathrm{g} \mathrm{chl} \mathrm{a} \mathrm{g}^{-1} \mathrm{DW}$; Riaux 1983).

The most important difference between winter and spring samples from Frêt is the increase of fucoxanthin and phaeophytin a-like in spring; the latter is the result of grazing (see below) which is generally more intense during summer. Chlorophyll $b$, on the other hand, seems to decrease at spring, possibly indicating succession between Bacillariophyceae and Chlorophyceae. At Pierre Noire the phaeophorbide a-like, fucoxanthin

Table 2. HPLC pigment concentrations $\left(\mu \mathrm{g} \mathrm{g}^{-1} \mathrm{DW}\right)$ of sediment samples from Frêt (Rade de Brest)

\begin{tabular}{|c|c|c|c|c|}
\hline \multirow[t]{2}{*}{ Pigment } & \multicolumn{2}{|c|}{1 Mar 1985} & \multicolumn{2}{|c|}{14 May 1985} \\
\hline & $0-0.5 \mathrm{~cm}$ & $6-8 \mathrm{~cm}$ & $0-0.5 \mathrm{~cm}$ & $6-8 \mathrm{~cm}$ \\
\hline Unidentified polar a pigment & 1.027 & 0.294 & 2.65 & $<\mathrm{DL}$ \\
\hline Chlorophyllide a & 0.133 & $<\mathrm{DL}$ & 0.709 & $<D L$ \\
\hline Chlorophyll $c$ & 0.285 & $<\mathrm{DL}$ & 1.156 & $<D L$ \\
\hline Phaeophorbide a & 7.56 & 0.72 & 8.056 & 0.47 \\
\hline Phaeophorbide a-like & 3.92 & 0.56 & 16.63 & 0.47 \\
\hline Chlorophyll b & 4.78 & 0.63 & 2.43 & $<\mathrm{DL}$ \\
\hline Chlorophyll a-allomer & 1.58 & 0.30 & 1.25 & 0.78 \\
\hline Chlorophyll a & 18.63 & 1.355 & 26.08 & 2.23 \\
\hline Phaeophytin a & 1.82 & 0.59 & 2.77 & 0.69 \\
\hline 'Pyrochlorophyll a' & 0.79 & 0.46 & 0.81 & 0.35 \\
\hline Fucoxanthin & 4.03 & 0.25 & 7.64 & 0.38 \\
\hline Lutein & 1.94 & 0.61 & 1.86 & 0.86 \\
\hline$<D L$ : below detection limit & & & & \\
\hline
\end{tabular}

Table 3. HPLC pigment concentrations ( $\mu \mathrm{g} \mathrm{g}^{-1} \mathrm{DW}$ ) of sediment samples from Pierre Noire (Baie de Morlaix)

\begin{tabular}{|lcccccc|}
\hline \multirow{2}{*}{ Pigment } & \multicolumn{2}{c}{28 Feb 1985} & \multicolumn{2}{c}{13 May 1985} & \multicolumn{2}{c}{10 Jun 1985} \\
& $0-0.5 \mathrm{~cm}$ & $6-8 \mathrm{~cm}$ & $0-0.5 \mathrm{~cm}$ & $6-8 \mathrm{~cm}$ & $0-0.5 \mathrm{~cm}$ & $6-8 \mathrm{~cm}$ \\
\hline Chlorophyll c $c_{1}+c_{2}$ & 0.054 & 0.056 & 0.108 & 0.034 & 0.186 & 0.064 \\
Phaeophorbide a & 0.366 & 0.348 & 2.367 & 0.072 & 3.596 & 0.534 \\
Phaeophorbide a-like & 0.670 & 0.542 & 5.266 & 1.290 & 12.494 & 1.110 \\
Phaeophorbide a-like & 0.112 & 0.080 & 0.216 & 0.088 & 0.888 & 0.094 \\
Chlorophyll b & 0.434 & 0.190 & 0.172 & 0.292 & 0.480 & 0.354 \\
Chlorophyll a-allomer & 0.420 & 0.138 & 0.286 & 0.070 & 0.446 & 0.150 \\
Chlorophyll a & 2.318 & 2.026 & 2.780 & 1.600 & 5.760 & 2.586 \\
Phaeophytin a & 0.114 & 0.210 & 0.206 & 1.600 & 0.608 & 0.280 \\
Fucoxanthin & 0.673 & 0.452 & 1.178 & 0.461 & 3.176 & 0.783 \\
\hline
\end{tabular}


and chlorophyll a concentrations show obvious seasonal variations (consistent increase during summer: Fig. 7).

The stratification in the thickness of the 2 sediments is obvious (Fig. $7 \& 8$ ); the differences between the surface $(0$ to $0.5 \mathrm{~cm}$ ) and the deeper layer $(6$ to $8 \mathrm{~cm})$ are more significant in the mud. This can also be explained by the different dynamics of the 2 sediments

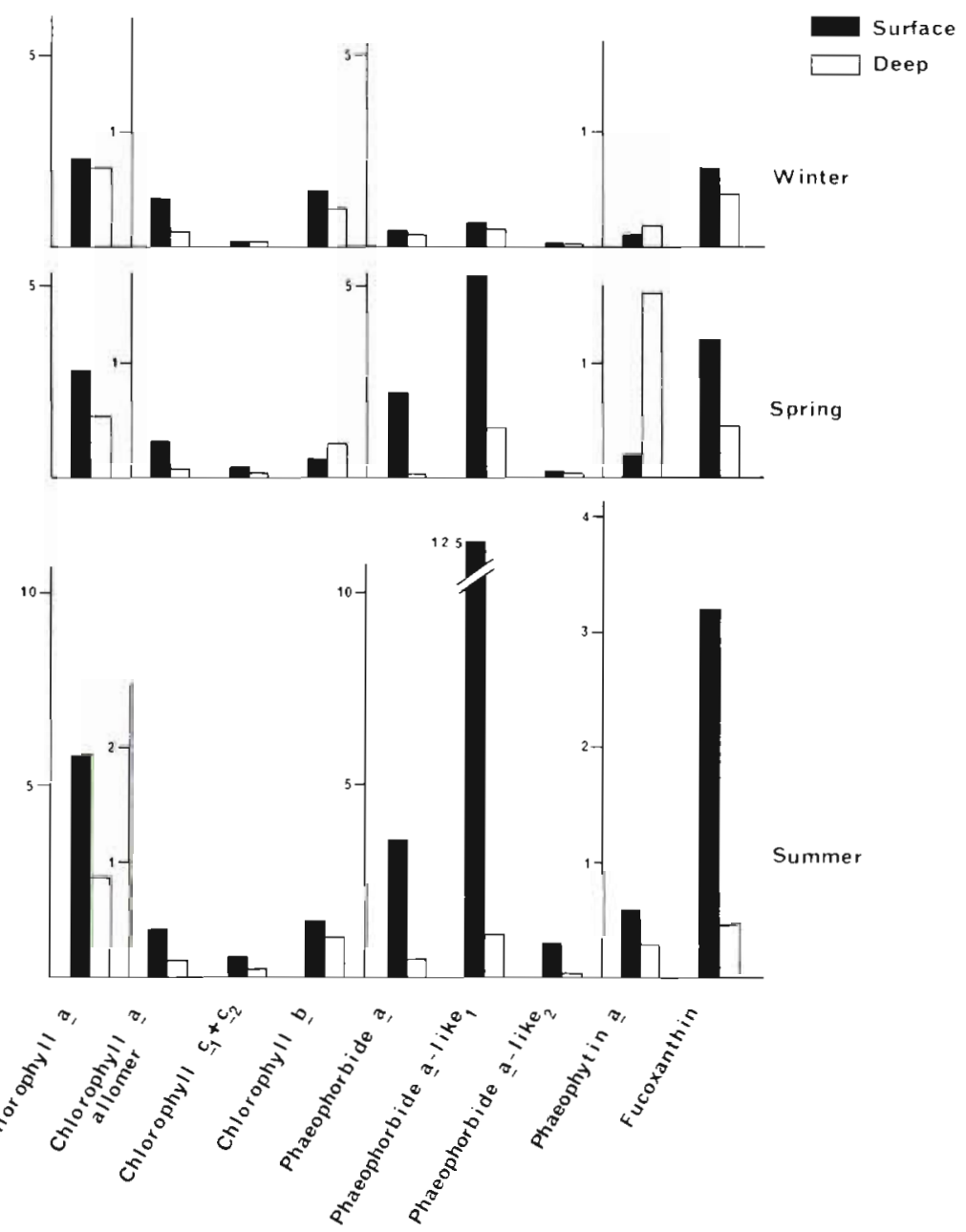

Fig. 7. Seasonal variations of pigment concentrations $\left(\mu \mathrm{g} \mathrm{g}^{-1} \mathrm{DW}\right)$ at Pierre Noire. Black bars: 0 to $0.5 \mathrm{~cm}$ sample; open bars: 6 to $8 \mathrm{~cm}$ layer

Table 4. 'Chlorophyll $a^{\prime}$ and phaeopigment concentrations $\left(\mu \mathrm{g} \mathrm{g}^{-1} \mathrm{DW}\right)$ determined by the fluorometric method

\begin{tabular}{|c|c|c|c|c|c|c|}
\hline $\begin{array}{l}\text { Sampling } \\
\text { location }\end{array}$ & $\begin{array}{l}\text { Nature of } \\
\text { sediment }\end{array}$ & $\begin{array}{c}\text { Date } \\
(1985)\end{array}$ & $\begin{array}{l}\text { Layer } \\
(\mathrm{cm})\end{array}$ & $\begin{array}{l}\text { Chl. a } \\
\text { ( } \mu g\end{array}$ & $\begin{array}{l}\text { Phaeo. } \\
\text { W) }\end{array}$ & $\begin{array}{l}\% \text { dry matter } \\
\text { in sediment }\end{array}$ \\
\hline $\begin{array}{l}\text { Frêt } \\
\text { (Rade de Brest) }\end{array}$ & $\begin{array}{l}\text { Subtidal mud } \\
\text { depth: } 10 \mathrm{~m}\end{array}$ & $\begin{array}{l}1 \text { Mar } \\
14 \text { May }\end{array}$ & $\begin{array}{l}0-0.5 \\
6-8 \\
0-0.5 \\
6-8\end{array}$ & $\begin{array}{r}9.27 \\
1.72 \\
22.06 \\
2.57\end{array}$ & $\begin{array}{r}18.66 \\
4.54 \\
17.37 \\
3.93\end{array}$ & $\begin{array}{l}34.74 \\
55.96 \\
34.18 \\
56.60\end{array}$ \\
\hline $\begin{array}{l}\text { Pierre Noire } \\
\text { (Baie de Morlaix) }\end{array}$ & $\begin{array}{l}\text { Subtidal sand } \\
\text { depth: } 20 \mathrm{~m}\end{array}$ & $\begin{array}{l}28 \text { Feb } \\
13 \text { May } \\
10 \text { Jun }\end{array}$ & $\begin{array}{l}0-0.5 \\
6-8 \\
0-0.5 \\
6-8 \\
0-0.5 \\
6-8\end{array}$ & $\begin{array}{l}2.98 \\
2.80 \\
3.82 \\
1.62 \\
5.42 \\
0.67\end{array}$ & $\begin{array}{r}2.31 \\
2.34 \\
6.85 \\
2.25 \\
13.84 \\
2.76\end{array}$ & $\begin{array}{l}67.51 \\
68.08 \\
66.37 \\
68.84 \\
66.80 \\
67.30\end{array}$ \\
\hline
\end{tabular}


the sand is continually reworked by wave action (ripple marks are always present), and epibenthic macrofauna, mainly amphipods (Dauvin 1984), cause an active bioturbation. A more detailed description of the 'chlorophyll $a^{\prime}$ and phaeopigments distribution in space and time is given in Part I (Riaux-Gobin unpubl.).

\section{DISCUSSION}

The pigment diversity detected in these 2 subtidal sediments, particularly in the mud, is greater than in the phytoplankton samples collected the same year in Morlaix Bay (Klein \& Sournia 1987), indicating that these pigments originate mainly from an autochthonous microphytobenthic population and not only from sedimented phytoplankton. Furthermore the chlorophyll $b$ content relative to chlorophyll $a$ is much higher in the sediments. Phaeopigments and carotenoids are particularly numerous and abundant in these sediments. Such a great pigment diversity indicates the complexity of these benthic communities that are confined to the first few millimeters of sediment.

The most important chlorophyll a degradation product at the 2 stations is a phaeophorbide a-like pigment (phaeophytin a is only a minor pigment). Such a pigment was also observed by Vernet (1983), Gieskes \& Kraay (1986) and Roy (1986). Hawkins et al. (1986) concluded that phaeophorbide a-like pigments are the primary indicators of feeding processes. Meiofauna (mainly nematodes and harpacticoid copepods) are abundant in such shallow sediments (Boucher et al. 1984) and are probably able to digest algal pigments. It should also be noticed that neither intact pigments nor degraded pigments accumulate in the deeper layers of the sediments; they are concentrated at the surface. This demonstrates the fast mineralisation and recycling of these organic compounds, possibly following Treibs reaction scheme (1936). Very few publications deal with pigment degradation processes in sediments; but, in freshwater sediments, carotenoids seem not to be affected by fast degradation (Züllig 1982). The rela-
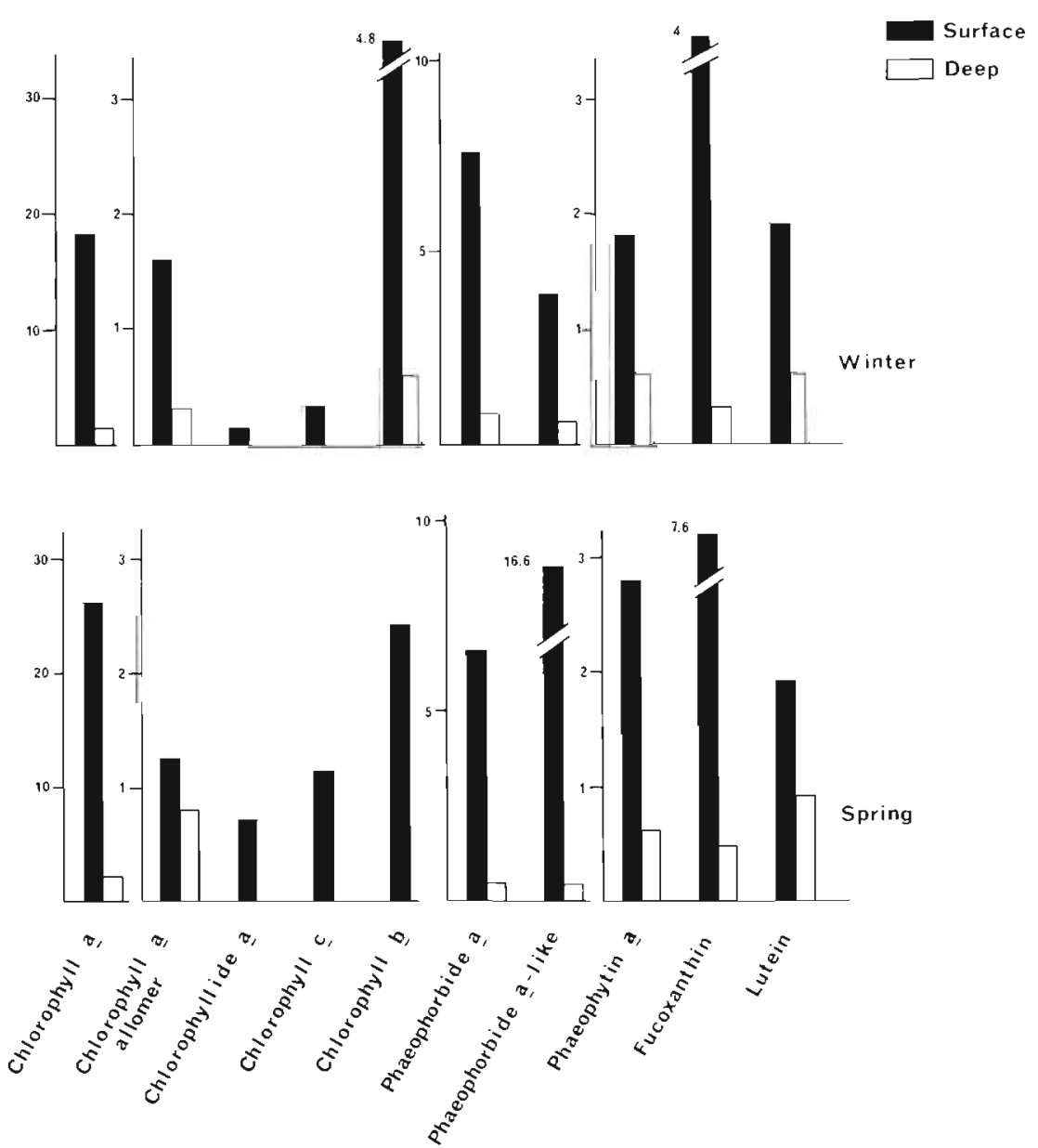

Fig. 8. Seasonal variations of pigment concentrations $\left(\mu \mathrm{g} \mathrm{g}^{-1} \mathrm{DW}\right)$ at Frêt. Black bars: 0 to $0.5 \mathrm{~cm}$ samples; open bars: 6 to $8 \mathrm{~cm}$ layer 
tively large carotene peaks ( $\alpha$ and $\beta$-carotene) in both surface and deep layers indicate that these pigments are rather stable (e.g. Watts \& Maxwell 1977).

Acknowledgements. This study received financial support from the E.E.C. (AZOC contract). The GABIM meeting (1985 at Concarneau, France) was at the basis of this collaboration. B. K. acknowledges the grant from the Minna-JamesHeineman-Stiftung.

\section{LITERATURE CITED}

Abaychi, J. K., Riley, J. P. (1979). The determination of phytoplankton pigments by high performance liquid chromatography. Analytica chim. Acta 107: 1-11

Asmus, R. (1982). Field measurements on seasonal variation in the activity of primary producers on a sandy tidal flat in the northern. Wadden Sea. Neth. J. Sea Res. 16: 389-402

Boucher, G., Chamroux, S., Riaux, C. (1984). Modifications des caractéristiques physico-chimiques et biologiques d'un sable sublittoral pollué par hydrocarbures. Mar. environ. Res. 12: 1-24

Brown, L. M., Hargrave, B. T., Mackinnon, M. D. (1981) Analysis of chlorophyll a in sediments by high-pressure liquid chromatography. Can. J. Fish. Aquat. Sci. 38: 205-214

Cadée, G. C., Hegeman, J. (1974). Primary production of the benthic microflora living on tidal flats in the Dutch Wadden Sea. Neth. J. Sea Res. 8: 260-291

Conover, R. Y., Durvasala, R., Roy, S., Wang, R. (1986). Probable loss of chlorophyll-derived pigments during passage through the gut of zooplankton, and some of the consequences. Limnol. Oceanogr. 31:878-887

Daemen, E. A. M. (1986). Comparison of methods for the determination of chlorophyll in estuarine sediments. Neth. J. Sea Res. 20: 21-28

Dauvin, J.-C. (1984). Dynamique d'ecosystemes macrobenthiques des fonds sédimentaires de la Baie de Morlaix et leur perturbation par les hydrocarbures de l'Amoco Cadiz. Thèse Doc. Sci. Nat., Univ. Paris

Gieskes, W W. C., Kraay, G. W. (1984). Phytoplankton, its pigments, and primary production at a central North Sea station in May, July and September 1981. Neth. J. Sea Res. 18: $51-70$

Gieskes, W W. C., Kraay, G. W. (1986). Floristic and physiological differences between the shallow and the deep nanophytoplankton community in the euphotic zone of the open tropical Atlantic revealed by HPLC analysis of pigments. Mar. Biol. 91: 567-576

Hafsaoui, M. (1984). Fertilisation d'un système eutrophe à forte variabilité saisonnière et annuelle. Facteurs limitant de la production phytoplanctonique, assimilation simultanée des différentes formes d'azote inorganique et organique. Thèse 3ème Cycle. Univ. de Bretagne Occidentale Brest

Hawkins, A. J. S., Bayne, B. L., Mantoura, R. F. C., Llewellyn, C. A., Navarro, E. (1986). Chlorophyll degradation and absorption through the digestive system of the blue mussel Mytilus edulis L. J. exp. mar Biol. Ecol 96: 213-220

Hoek, C van den (1978). Algen. Einführung in die Phycologie. Thieme, Stuttgart

Holm-Hansen, O., Lorenzen, C. J., Holmes, R. W., Strickland, J. D. H. (1965). Fluorometric determination of chlorophyll, J. Cons. perm. int. Explor. Mer. 30: 3-15
Jacobsen, T. R. (1982). Comparison of chlorophyll a measurements by fluorometric, spectrophotometric and high pressure liquid chromatographic methods in aquatic environments. Arch. Hydrobiol. Beih. Ergeb. Limnol. 16: $35-45$

Jeffrey, S. W (1980). Algal pigment systems. In: Falkowski P. G. (ed.) Primary productivity in the sea. Plenum Press New York, p. 35-58

Jeffrey, S. W. (1981). An improved thin-layer chromatographic technique for marine phytoplankton pigments. Limnol. Oceanogr. 26: 191-197

Joint, J. R. (1978). Microbial production of an estuarine mudflat. Estuar. coast. mar. Sci. 7: 185-195

Klein, B., Sournia, A. (1987). A daily study of the diatom spring bloom at Roscoff (France) in 1985. II. Phytoplankton pigment composition studied by HPLC analysis. Mar Ecol. Prog. Ser. 37: 265-275

Lorenzen, C. J. (1966). A method for the continuous measurement of in vivo chlorophyll concentration. Deep Sea Res. 13: $223-227$

Lorenzen, C. J. (1967). Determination of chlorophyll and phaeophytin spectrophotometric equation. Limnol. Oceanogr. 12: 343-346

Lorenzen, C. J., Jeffrey, S. W. (1980). Determination of chlorophyll in seawater. U.N.E.S.C.O. Technical papers in marine science 35

Mantoura, R. F. C., Llewellyn, C. A. (1983). The rapid determination of algal chlorophyll and carotenoid pigments and their breakdown products in natural waters by reversephase high-performance liquid chromatography. Analytica chim. Acta 151: 297-314

Plante-Cuny, M.-R. (1974). Evaluation par spectrophotométrie des teneurs en chlorophylle a fonctionnelle et en phéopigments des substrats marins. Doc. Sci. Mission ORSTOM NosyBé 45: 1-76

Riaux, C. (1982). La chlorophylle a dans un sédiment estuarien de Bretagne Nord. Annls Inst. océanogr., Paris 58: 185-203

Riaux, C. (1983). Microphytes de l'interface 'eau-sédiment' dans une ria de Bretagne Nord: peuplements, biomasse, production, cycle annuel, variabilité à court terme. Thèse Doc. Sci. Nat., Univ. Paris

Riaux-Gobin, C., Douchement, C., Tréguer, P. (1987). Microphytobenthos de deux sédiments subtidaux de Nord Bretagne. III: Relations avec les sels nutritifs azotés de l'eau interstitielle et deux facteurs hydroclimatiques. Hydrobiologia (in press)

Round, F. E. (1971). Benthic marine diatoms. Oceanogr. mar. Biol. A. Rev. 9: 83-139

Roy, S. (1986). Marine chloropigments: chromatographic measurement in phytoplankton and transformations in algal cultures and a spring-bloom event in a marine bay. Ph. D. thesis, Dalhousie Univ., Halifax

Sartory, D. P. (1.985). The determination of algal chlorophyllous pigments by high performance liquid chromatography and spectrophotometry. Wat. Res. 19: 605-610

Sournia, A. (1977). Analyse et bilan de la production primaire dans les récifs coralliens. Annls Inst. océanogr., Paris 53: $47-74$

Strickland, J. D. H., Parsons, T R. (1968). A practical handbook of seawater analysis. Bull. Fish. Res. Bd Can. 167: $1-311$

Trees, C. C., Kennicut, M. C., IJ, Brooks. J. M. (1985). Errors associated with standard fluorimetric determination of chlorophylls and phaeopigments. Mar. Chem. 17: 1-12

Tréguer, P., Delmas, R., Le Jéhan, S. (1985). Conservativité et non conservativité de la distribution des matières nutri- 
tives et organiques, dissoutes et particularies, en écosystème marin et estuarien macrotidal. Océanis 11 169-195

Treibs, A. (1936). Chlorophyll- und Häminderivate in organischen Mineralstoffen. Angew. Chem. 49:682

Vernet, M. (1983). Marine phytoplankton pigments: methods and ecology. Ph. D. thesis, Univ. Washington, Seattle

Watts, C. D., Maxwell, J. R. (1977). Carotenoid diagenesis in a marine sediment. Geochim. cosmochim. Acta 41: 493-497
Yentsch, C. S., Menzel, D. W. (1963). A method for the determination of phytoplankton chlorophyll and phaeophytin by fluorescence. Deep Sea Res. 10: 1221-1231

Züllig, H. (1982). Untersuchungen über die Stratigraphie von Carotenoiden im geschichteten Sediment von 10 Schweizer Seen zur Erkundung früherer PhytoplanktonEntfaltungen. Schweiz. Z. Hydrol. 44: 1-98

This article was submitted to the editor; it was accepted for printing on August 14, 1987 